\title{
Venous System Smooth Muscle Tissue
}

National Cancer Institute

\section{Source}

National Cancer Institute. Venous System Smooth Muscle Tissue. NCI Thesaurus. Code C49321.

The non-striated muscle tissue surrounding the blood vessels that are part of the venous system. 